\title{
Pseudoaneurysm of the left ventricle following apical approach TAVI
}

\author{
Andrew P Vanezis ${ }^{1 *}$, Mirza K Baig ${ }^{2}$, lan M Mitchel ${ }^{2}$, Matloob Shajar², Surendra K Naik², Robert A Henderson ${ }^{2}$ and \\ Thomas Mathew ${ }^{2}$
}

\begin{abstract}
Symptomatic severe aortic stenosis carries a two year survival of only $50 \%$. However many patients are unsuitable for conventional aortic valve replacement as they are considered too high risk due to significant co-morbidities. Transcatheter Aortic Valve Implantation (TAVI) offers a viable alternative for this high risk patient group, either by the femoral or apical route. This article reports a case of a pseudoaneurysm of the left ventricle following an apical approach TAVI in an elderly lady with severe aortic stenosis. To our knowledge pseduoaneuryms of the left ventricle have been reported infrequently in the literature and has yet to be established as a recognised complication of TAVI.
\end{abstract}

\section{Background}

Symptomatic severe aortic stenosis carries a two year survival of only $50 \%$. However many patients are unsuitable for conventional aortic valve replacement as they are considered too high risk due to significant co-morbidities. Transcatheter Aortic Valve Implantation (TAVI) offers a viable alternate for this high risk patient group, either by the femoral or apical route. The procedure was first described in 2002 by Cribier et al [1] and several registries have subsequently been established that indicate a procedural success rate of over $90 \%$. This has allowed TAVI to become a viable treatment of aortic stenosis in a carefully selected group of patients where the risks of conventional surgery are thought to be too high[2-4].

This article reports a case of a pseudoaneurysm of the left ventricle (LV) following an apical approach TAVI in an elderly lady with severe aortic stenosis. To our knowledge pseduoaneuryms of the left ventricle have been reported only infrequently in the literature and it has yet to be established as a recognised complication of TAVI [5,6].

\section{Case Presentation}

We report the case of an 86 year old British Caucasian lady with severe aortic stenosis (peak gradient $62 \mathrm{mmHg}$,

\footnotetext{
* Correspondence: andrewvanezis@doctors.org.uk

'Department of Cardiovascular Sciences, University of Leicester, Clinical Sciences Wing, Glenfield General Hospital, Groby Road, Leicester, UK. LE3 9QP

Full list of author information is available at the end of the article
}

mean gradient $32 \mathrm{mmHg}$, valve area $0.4 \mathrm{~cm}^{2}$ ) who described worsening dyspnoea and chest discomfort on minimal exertion. Her past medical history included coronary artery bypass grafting, hypertension and diabetes mellitus type 2 .

She was deemed too high risk for conventional surgery and therefore underwent transapical approach TAVI with the implantation of a $23 \mathrm{~mm}$ Edwards Scientific Sapien $\mathrm{XT}$ valve prosthesis (a bovine tissue valve inserted on a cobalt chromium frame). Immediate transoephageal echocardiography and fluoroscopic imaging demonstrated excellent seating of the valve, subsequently confirmed angiographically.

Two days later the patient developed isolated electrocardiographic evidence of pericarditis with minimal associated chest pain. Transthoracic echocardiography demonstrated a well seated aortic prosthesis and a $0.8 \mathrm{~cm}$ pericardial effusion with no tamponade. The effusion was not drained and her electrocardiographic changes settled over the next few days. Three months later, transthoracic echocardiography showed an abnormal bidirectional signal at the apex (Additional File 1). Peak velocity was $139.4 \mathrm{~cm}^{-1}$. Cardiovascular magnetic resonance (CMR) showed a discrete pseudoaneurysm with late gadolinium myocardial enhancement (Additional Files 2 and 3). The decision was made to treat her conservatively and keep her under regular surveillance.
C Biomed Central

() 2011 Vanezis et al; licensee BioMed Central Ltd. This is an Open Access article distributed under the terms of the Creative Commons Attribution License (http://creativecommons.org/licenses/by/2.0), which permits unrestricted use, distribution, and reproduction in any medium, provided the original work is properly cited. 


\section{Conclusions}

The 30 day mortality of tranapical approach TAVI is reported by various registries at just over $10 \%[3,4]$. Well recognised complications of TAVI via the transapical approach include bleeding, cerebral vascular events and septal haematomas. However there are few reports of pseudoaneuryms and this case helps to reinforce this outcome as a recognised complication of this procedure.

\section{Consent}

Written informed consent was obtained from the patient for the publication of this case report and accompanying images. A copy of the written consent is available for review by the Editor-in-Chief of this journal.

\section{Additional material}

Additional file 1: 4 chamber view transthoracic echocardiogram of the LV showing colour flow in and out of the pseudoaneurysm. Additional file 2: CMR steady state free precession (SSFP) sequence showing pseudoaneurysm of the LV apex at the incision site. Additional file 3: First pass gadolinium scan showing flow into the pseudoaneurysm

\section{Abbreviations}

CMR: Cardiac Magnetic Resonance; LV: Left Ventricle; SSPF: Steady State Free Precession imaging; TAVI: Transcatheter Aortic Valve Implantation.

\section{Acknowledgements and Funding}

Nil funding

\section{Author details}

'Department of Cardiovascular Sciences, University of Leicester, Clinical Sciences Wing, Glenfield General Hospital, Groby Road, Leicester, UK. LE3 9QP. ${ }^{2}$ Trent Cardiac Centre, Nottingham University Hospital, Hucknall Road, Nottingham, UK. NG5 1PB.

\section{Authors' contributions}

APV was the primary author of the text. TM conceived of the report, acted as chief editor, provided the images and was the primary physician during the patient's inpatient stay. MKB, IMM, MS, SKN and RAH were involved in the patient's care as well as editing and overseeing of the text. All authors read and approved the final manuscript.

\section{Competing interests}

The authors declare that they have no competing interests.

Received: 18 September 2011 Accepted: 12 December 2011 Published: 12 December 2011

\section{References}

1. Cribier A, Eltchaninoff H, Bash A, Borenstein N, Tron C, Bauer F, Derumeaux G, Anselme F, Laborde F, Leon MB: Percutaneous transcatheter implantation of an aortic valve prosthesis for calcific aortic stenosis: first human case description. Circulation 2002, 106:3006-8.

2. Piazza N, Grube E, Gerckens U, den Heijer P, Linke A, Luha O, Ramondo A, Ussia G, Wenaweser P, Windecker S, Laborde JC, de Jaegere P, Serruys PW: Procedural and 30-day outcomes following transcatheter aortic valve implantation using the third generation (18 Fr) CoreValve ReValving system: results from the multicentre, expanded evaluation registry 1-year following CE mark approval. Eurolnterv 2008, 4:242-9.
3. Thomas M, Schymik G, Walther T, Himbert D, Lefèvre T, Treede H, Eggebrecht H, Rubino P, Michev I, Lange R, Anderson WN, Wendler O: Thirty-day results of the SAPIEN aortic bioprosthesis European outcome (SOURCE) registry. A European registry of transcatheter aortic valve implantation using the Edwards SAPIEN valve. Circulation 2010, 122:62-9.

4. Rodés-Cabau J, Webb JG, Cheung A, Ye J, Dumont E, Feindel CM, Osten M, Natarajan MK, Velianou JL, Martucci G, DeVarennes B, Chisholm R, Peterson MD, Lichtenstein SV, Nietlispach F, Doyle D, DeLarochellière R, Teoh K, Chu V, Dancea A, Lachapelle K, Cheema A, Latter D, Horlick E: Transcatheter aortic valve implantation for the treatment of severe symptomatic aortic stenosis in patients at very high or prohibitive surgical risk: acute and late outcomes of the multicenter Canadian experience. J Am Coll Cardiol 2010, 55:1080-90.

5. Elhenawy A, Rocha R, Feindel CM, Brister SJ: Persistent Left Ventricular False Aneurysm after Transapical Insertion of an Aortic Valve. J Card Surg 2011, 26:51-53.

6. Al-Attar N, Ghodbane W, Himbert D, Rau C, Raffoul R, Messika-Zeitoun D, Brochet $E$, Vahanian A, Nataf P: Unexpected complications of transapical valve implantation. Ann Thorac Surg 2009, 88:90-94.

doi:10.1186/1532-429X-13-79

Cite this article as: Vanezis et al:: Pseudoaneurysm of the left ventricle following apical approach TAVI. Journal of Cardiovascular Magnetic Resonance 2011 13:79.

\section{Submit your next manuscript to BioMed Central and take full advantage of:}

- Convenient online submission

- Thorough peer review

- No space constraints or color figure charges

- Immediate publication on acceptance

- Inclusion in PubMed, CAS, Scopus and Google Scholar

- Research which is freely available for redistribution 